\title{
MICROTEACHING: AN EFFECTIVE TOOL TO ENHANCE THE TEACHING SKILLS
}

\author{
Yogesh Popat \\ Principal, Delhi Public Elementary School, \\ Indore, M.P, India
}

\begin{abstract}
This paper depicts the utilization of microteaching session for the analysis of attitude and perception of teachers towards microteaching to enhance their core competencies in teaching skill. The session was conducted for three days at one of the day schools in Indore, The Delhi Public Elementary School. The qualitative and quantitative methods were used and the presentation session was conducted for the teachers to analyse the skills of group of 30 teachers. The finding of the study reflects that there is a drastic build in confidence, attitude and perception of the teacher before and after the micro teaching session was conducted. A questionnaire and an interview session was also conducted at the end of every presentation and the finding shows that teachers believed that this session gives a chance to understand their weakness and strength related to their professional teaching. The results also reflect that the teachers were able to establish the skills of: planning, demonstration, explaining learning outcomes, assessment and management of student's behaviours. At the end of the session teachers also agreed to common conclusion that the microteaching session must be the part of the routine process of every school, which not helped them to build confidence and improve their skill but it also helped to share the teaching methodology among each other.
\end{abstract}

Keywords- microteaching, core competencies, teaching skill, attitude, perception, confidence.

\section{INTRODUCTION}

Teacher's training has gained importance in current education system and the conduction of microteaching sessions is very much popular now a-days and opted by many of the renowned educational institutions and organizations. This method was first implemented by Allen and colleagues as a part of experimental program at the Stanford University, USA. This was considered to be one of the innovations of that time. The structure was developed at a later stage [1].

Education is the ancient concept in the history which is now an important and integral part of our society. Since 1960, microteaching was considered to be an important part of teacher's training before they enter in the field of actual professional teaching. The prefix 'micro' has an origin from a Greek word which means small. It is a kind of teachers training not only for the pre service teachers but also for the service teachers which helps them to refine their skill, knowledge, way of demonstration and more specifically the planning and execution part [2].

Success motivation is a key factor for an individual. Microteaching aims at making the teachers adopt the character they will have in the classroom. Video recording and peer assessment has also proven to be a significant way of assessment of microteaching of an individual [3]. Peer assessment also helps in developing higher order thinking skills (HOTS) as far as the young generation is concerned [4]. HOTS can be considered as a complex mode of thinking which results in multiple solutions [5]. HOTS also includes metacognitive, critical and logical thinking [6].

Nowa-days, the microteaching has also become a proven tool to relate and utilize technology with teaching which is very much needed in the present scenario. The teachers need to update themselves with the current trends of teaching, curriculum and recent advancement going on in the education industry as far as India is concerned. The effectiveness of these kinds of sessions entirely depends on the participant's belief and their involvement during the session. The objective of this study is to analyse and understand that whether these kinds of sessions are really helpful for the teachers to improve their skills or not [7].

\section{BACKGROUND}

Previous researches indicate that microteaching is useful for improving the skills of pre service teachers as well as the service teachers. Gorgen [8] in his research indicated

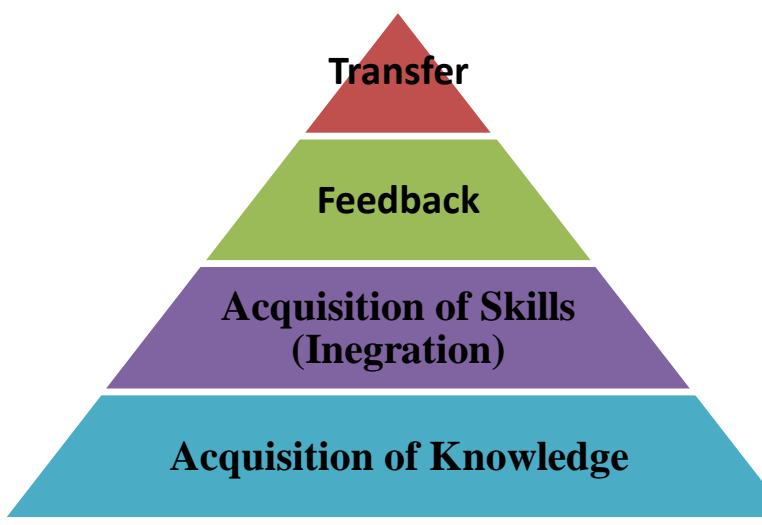

that the views of 24 pre-service teachers pose some differences before and after the microteaching session. Amobi [9] examined the significant output by including 


\section{International Journal of Engineering Applied Sciences and Technology, 2020 \\ Vol. 5, Issue 8, ISSN No. 2455-2143, Pages 198-206 \\ Published Online December 2020 in IJEAST (http://www.ijeast.com)}

31 pre service teachers during second session of microteaching. The study was streamlined to the recurrent themes of reflectivity of self-and peer-evaluations. La Maistre \& Pare [10] in their paper indicated that getting a degree is not enough to be a professional teacher for live class room; they must be prepared through the transition process.

\section{PROBLEM STATEMENT}

Training for the teachers especially for in service teachers has always become a challenge as far as the Indian education system is concerned. Following are some of the factors of consideration:

(i) Gap between the training programs for the teachers and existing evaluation system in Indian education system.

(ii) Complexity in the teaching process [11]

(iii) Always in the workshops and seminars there is a talk about the required teaching skills but practicing it to the mastery is always neglected.

\section{THE CONCEPTUAL FRAMEWORK}

The traditional teaching mainly focuses on the delivery of the factual knowledge and it is more of teacher centered instead of child centric. The teachers are the main source of information and there is shift from teacher centered learning to student centric learning. So, the role of the teacher is very crucial and important at this point of time. The microteaching method is one of the tools to fulfill this requirement.

The conceptual framework of the microteaching process comprises of four basics steps as indicated in Figure 1. The four steps of the process are Acquisition of knowledge, Acquisition of skill, Feedback process and Transfer of the learning phase. $[12,13]$

\section{Figure1. Basic Phases of the Microteaching Process [12]}

The Knowledge acquisition phase is the beginning step in which the teachers gets trained to various teaching processes like lesson plan preparation, utilization of more and more teaching aids, body language and other skills. The colleagues can act as peer assessor for constructive feedback and the learned methodology and training points can be used for live classroom teaching and that's what we call the transfer phase [14].

In between the skill acquisition and feedback phase there is a cyclic process which must be considered for getting optimized output in microteaching session, the cyclic process is indicated in Figure 2. While practicing microteaching session the lesson duration must be kept in between 15 to 20 minutes and the audience must consist 30 to 35 members. In the cyclic process of microteaching, the first step is the planning of lesson plan by the teachers for any pre-decided topic related to the subject. The video recording of the demonstration must be done and must be shown to the presenters for self analysis. The peer assessment or the assessment by an expert can also be done for getting a better feedback. In the criticizing stage the teacher's micro lesson plans and demonstrations were analysed and discussed. Again the process is repeated but with the modified version by considering the feedback of self analysis or analysis done by an expert or peer analysis. Again the video recording can be done to have comparative analysis of successive presentations by the teachers. Also the peer and the teacher can show the point of consideration or positive points of the presentation to their critiques between the first and the second micro lesson [15].

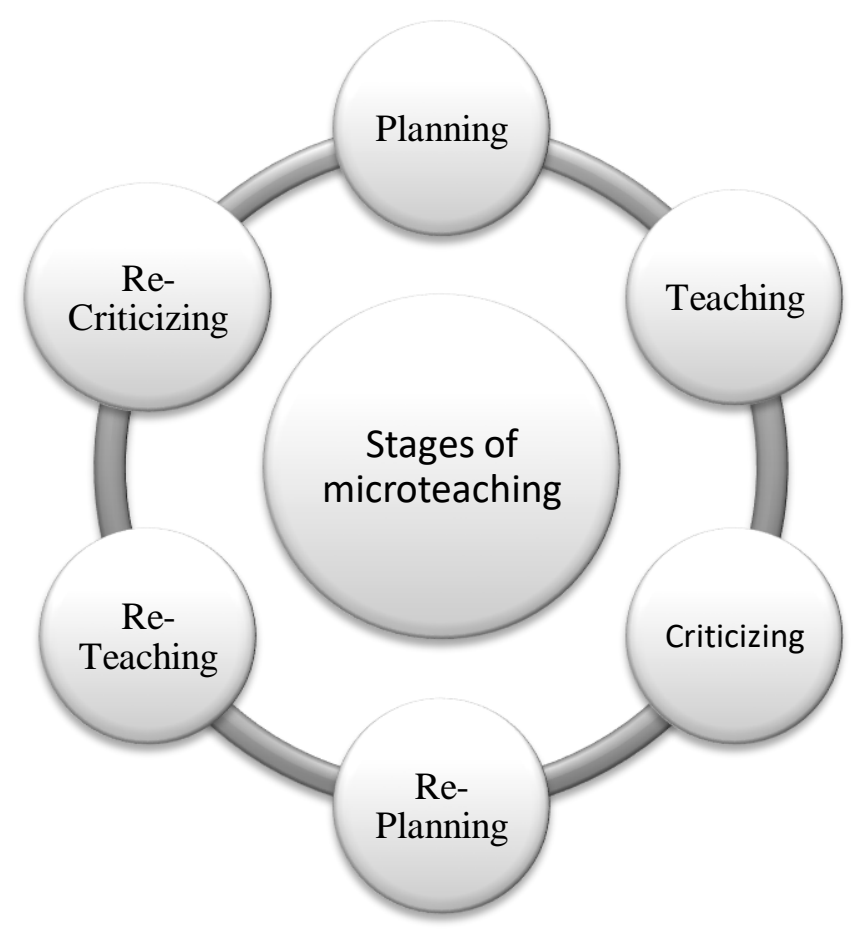

Figure2. Stages of microteaching [16]

\section{CORE SKILLS APPLICABLE IN TEACHING}

Teaching can be analysed by various teaching skills which are nothing but the set of behaviour or any act that facilitates teaching and learning processes directly or indirectly. During the origin of micro teaching session in 1960s, around 20 teaching skills have been identified but this figure has increased to 37. Few important skills are listed below.

\section{Lesson planning}

It involves the preparation of the lesson which is demonstrated during the session, the planning must be done in terms of sequencing of the topics, time management, relevance of the content and content to be covered in an allocated time frame. A sample format of a 


\section{International Journal of Engineering Applied Sciences and Technology, 2020 \\ Vol. 5, Issue 8, ISSN No. 2455-2143, Pages 198-206 \\ Published Online December 2020 in IJEAST (http://www.ijeast.com)}

lesson that has been utilized in this study is given in annexure-1.

\section{Presentation and explanation}

This includes the clarity of the delivered contents and understanding of the concepts. The sub components also include effective beginning, involvement of the audience, creating readiness, confidence, enthusiasm and proper recap of the content or more specifically summary explanation.

\section{Illustrating with the help of an example}

The teacher should be able to relate the contents with the real and daily life examples, which not only helps the learners to understand the concepts more easily but it also helps the learners to retain it for a long time.

\section{Stimulus variation}

Attracting the learner's attention and binding them to your way of content delivery is an imperative art of any good teacher and it is of utmost importance in any teaching learning process. The key components of this factor are voice modulation, gestures and change in interaction style.

\section{Probing questions}

Increasing critical awareness is very important for any teaching session. It is important to allow and encourage the learners to ask structured doubts, if they have and clarify it at that moment only.

\section{Reinforcement}

This is the way by which the interaction between the learners can be increased. Use of verbal or non-verbal cues or a kind of quiz or any fun activity can serve the purpose of reinforcement.

\section{Using audiovisual aids}

The video based instructional packages can be very useful for the learners to understand the contents and researches also reflect that the audio visual aids help to increase the retention power of the mind.

\section{Classroom management}

Directing the learners by using proper instructions, seating arrangement, restricting the unwanted and inappropriate behaviour of the learners are essential parameters of this skill. Table 1 indicates the summary of core skills needed for microteaching as well as real classroom teaching [17].

\begin{tabular}{|c|c|}
\hline Table 1 Core Teaching Sl & \\
\hline Lesson Planning & Probing Questions \\
\hline - $\begin{array}{l}\text { Content to be } \\
\text { delivered }\end{array}$ & - $\quad$ Seeking Further \\
\hline $\begin{array}{l}\text { - } \quad \text { Learning } \\
\text { Outcome }\end{array}$ & - $\quad$ Refocusing \\
\hline $\begin{array}{l}\text { - Sequencing of the } \\
\text { topics }\end{array}$ & - $\quad$ Awareness \\
\hline - $\quad$ Relevance & - $\quad$ Method of asking \\
\hline - $\quad$ Time frame & Reinforcement \\
\hline $\begin{array}{l}\text { Presentation } \\
\text { Explanation }\end{array}$ & - Verbal Cues \\
\hline - $\quad$ Fluency & - $\quad$ Non-Verbal Cues \\
\hline - Understanding & - $\quad$ Rephrasing \\
\hline - $\quad$ Clarity & - $\quad$ Prompting \\
\hline - $\quad$ Confidence & Audio Visual Aids \\
\hline - $\quad$ Energy Level & - $\quad$ Readability \\
\hline $\begin{array}{l}\text { Illustrating with } \\
\text { Examples }\end{array}$ & - Appropriateness \\
\hline $\begin{array}{ll}\text { - Interesting daily } \\
\text { life examples }\end{array}$ & - $\quad$ Adequate \\
\hline - $\quad$ Simple & - $\quad$ Clarity \\
\hline - Relevant & Classroom Management \\
\hline $\begin{array}{lll}- & \text { Retention } \\
& \text { long period }\end{array}$ & $\begin{array}{ll}- & \text { Seating } \\
& \text { Arrangement } \\
\end{array}$ \\
\hline Stimulus Variation & - $\quad$ Make norms \\
\hline - $\quad$ Gestures & $\begin{array}{ll}\text { - } & \begin{array}{l}\text { Direction } \\
\text { instructions }\end{array} \\
\end{array}$ \\
\hline $\begin{array}{ll}\text { - } & \text { Voice } \\
& \text { Modulation } \\
\end{array}$ & $\begin{array}{ll}\text { - } & \text { Keeping students } \\
\text { in eye span } \\
\end{array}$ \\
\hline $\begin{array}{lll}\text { - } & \text { Pausing and } \\
& \text { Focusing } & \end{array}$ & - $\quad$ Discipline \\
\hline - Interaction Style & $\begin{array}{l}\text { - Calling students by } \\
\text { name }\end{array}$ \\
\hline
\end{tabular}

The main aim of microteaching sessions is to simulate the teaching situation and project the learned skills in the real classroom situations. Figure 3 reflects the 10 key parameters in detail which must be considered as a ladder for conducting microteaching activity and for getting maximum output from the sessions [18]. 


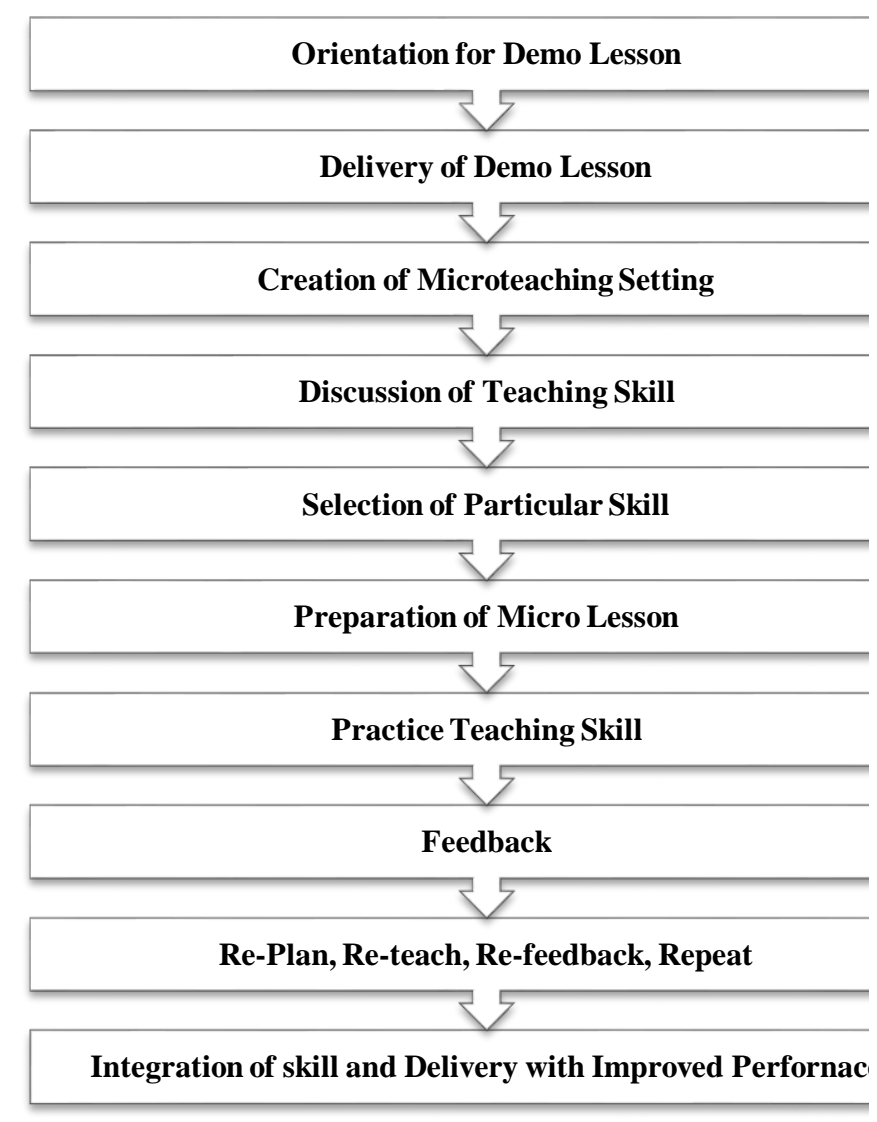

Figure3. Teaching ladder for effective teaching [19]

\section{OBJECTIVES OF THE RESEARCH}

- To boost up the level of confidence of in-service teachers.

- To develop procedure and internalize the steps involved for live classroom teaching.
- To determine the level of attitude and perception of in-service teachers towards microteaching.

- To utilize the academic potential of teachers for providing much needed feedback.

- To enable the teachers to master some teaching skills.

- To make the session to be meaningful and productive.

\section{METHODOLOGY AND RESULTS}

The most widely used method in the field of social sciences of descriptive survey has been adopted for this research. Also three days orientation and demo lesson presentation were conducted for all the teachers which are 30 in numbers followed by questionnaire session and focused group interview. All the teachers of different departments of Delhi Public Elementary School were considered as a sample for the research. The Total samples are 30 in numbers. On the very first day the demo lessons were presented by all the trained graduate teachers (TGTs) followed by Primary and Pre Primary

Teachers on the second day and all the co-scholastic departments on the third day. The duration of the demo lesson presentations were kept 20 minutes and oral feedback was shared by the respective peer assessor and the expert team which comprises of Mr. Dhruv Tiwari, Director of the School and Mr. Yogesh Popat, Principal of the School. Sample Assessment form is reflected in Annexure-2. The data collected was tabulated and analysed. Five points Likert scale was used, extending from strongly agree (SA), agree (A), undecided (UD), disagree (D) and strongly disagree (SD). The responses were made before and after the conduction of the session.

Tables 1,2 and 3 will reflect the teacher's perception, prediction and attitude towards the

Table1. Teacher's perception on the impact of microteaching on their teaching competence

\begin{tabular}{|l|l|l|l|l|l|l|l|}
\hline S.N. & Statements & SA & A & UD & D & SD & Total \\
\hline 1 & $\begin{array}{l}\text { Microteaching session is going to help } \\
\text { me develop awareness of my teaching } \\
\text { skills }\end{array}$ & $3(10 \%)$ & $15(50 \%)$ & $5(17 \%)$ & $6(20 \%)$ & $1(3 \%)$ & $30(100 \%)$ \\
\hline 2 & $\begin{array}{l}\text { Microteaching will provide an } \\
\text { opportunity to improve my planning }\end{array}$ & $3(10 \%)$ & $8(27 \%)$ & $18(60 \%)$ & - & $1(3 \%)$ & $30(100 \%)$ \\
\hline 3 & $\begin{array}{l}\text { Helpful for developing the actual } \\
\text { teaching skills needed for professional } \\
\text { teaching }\end{array}$ & $2(6 \%)$ & $12(40 \%)$ & $14(48 \%)$ & $1(3 \%)$ & $1(3 \%)$ & $30(100 \%)$ \\
\hline 4 & $\begin{array}{l}\text { Will give me an opportunity to apply } \\
\text { my learned skills }\end{array}$ & $6(20 \%)$ & $9(30 \%)$ & $14(48 \%)$ & - & $1(3 \%)$ & $30(100 \%)$ \\
\hline 5 & $\begin{array}{l}\text { Will be helpful in determining my } \\
\text { strength and weakness }\end{array}$ & $6(20 \%)$ & $3(10 \%)$ & $17(57 \%)$ & $3(10 \%)$ & $1(3 \%)$ & $30(100 \%)$ \\
\hline 6 & $\begin{array}{l}\text { Opportunity to learn by observing } \\
\text { others }\end{array}$ & $6(20 \%)$ & $1(3 \%)$ & $22(74 \%)$ & - & $1(3 \%)$ & $30(100 \%)$ \\
\hline
\end{tabular}


International Journal of Engineering Applied Sciences and Technology, 2020

Vol. 5, Issue 8, ISSN No. 2455-2143, Pages 198-206

Published Online December 2020 in IJEAST (http://www.ijeast.com)

\begin{tabular}{|l|l|l|l|l|l|l|l|}
\hline & & & & & & & \\
\hline 7 & $\begin{array}{l}\text { Will make me aware of what makes a } \\
\text { good teacher }\end{array}$ & $4(13.5 \%)$ & $4(13.5 \%)$ & $21(70 \%)$ & - & $1(3 \%)$ & $30(100 \%)$ \\
\hline 8 & $\begin{array}{l}\text { Will encourage me to learn classroom } \\
\text { management }\end{array}$ & $6(20 \%)$ & $3(10 \%)$ & $20(67 \%)$ & - & $1(3 \%)$ & $30(100 \%)$ \\
\hline 9 & $\begin{array}{l}\text { Will encourage me to develop } \\
\text { autonomy }\end{array}$ & $6(20 \%)$ & $3(10 \%)$ & $20(67 \%)$ & 0 & $1(3 \%)$ & $30(100 \%)$ \\
\hline 10 & $\begin{array}{l}\text { Will be helpful to organize and manage } \\
\text { the time frame }\end{array}$ & $6(20 \%)$ & $2(7 \%)$ & $21(70 \%)$ & 0 & $1(3 \%)$ & $30(100 \%)$ \\
\hline
\end{tabular}

Table2. Teacher's prediction on the effectiveness of the session

\begin{tabular}{|l|l|l|l|l|l|l|l|}
\hline S.N. & Statements & SA & A & UD & D & SD & Total \\
\hline 1 & $\begin{array}{l}\text { Microteaching: will help me to } \\
\text { boost my confidence in speaking } \\
\text { fluently }\end{array}$ & - & $5(17 \%)$ & $24(80 \%)$ & - & $1(3 \%)$ & $30(100 \%)$ \\
\hline 2 & $\begin{array}{l}\text { Will encourage me to apply the } \\
\text { ideas that I have learned in different } \\
\text { course }\end{array}$ & - & $6(20 \%)$ & $23(77 \%)$ & - & $1(3 \%)$ & $30(100 \%)$ \\
\hline 3 & $\begin{array}{l}\text { Will help me to determine the } \\
\text { Learning objectives }\end{array}$ & - & $3(10 \%)$ & $26(87 \%)$ & - & $1(3 \%)$ & $30(100 \%)$ \\
\hline 4 & $\begin{array}{l}\text { Will help me to write an effective } \\
\text { lesson plan }\end{array}$ & - & $6(20 \%)$ & - & $23(77 \%)$ & $1(3 \%)$ & $30(100 \%)$ \\
\hline 5 & $\begin{array}{l}\text { Will help me to use my teaching } \\
\text { aids effectively }\end{array}$ & - & $6(20 \%)$ & $23(77 \%)$ & - & $1(3 \%)$ & $30(100 \%)$ \\
\hline 6 & $\begin{array}{l}\text { Will give me the confidence to stand } \\
\text { and talk before a class }\end{array}$ & - & $6(20 \%)$ & $23(77 \%)$ & - & $1(3 \%)$ & $30(100 \%)$ \\
\hline
\end{tabular}

Table3. The attitude of the teacher's towards micro teaching

\begin{tabular}{|l|l|l|l|l|l|l|l|}
\hline S.N. & Statements & SA & A & UD & D & SD & Total \\
\hline 1 & Going to be time consuming & $1(3 \%)$ & $14(47 \%)$ & $12(40 \%)$ & $3(10 \%)$ & - & $30(100 \%)$ \\
\hline 2 & $\begin{array}{l}\text { Going to be boring and stressing } \\
\text { session }\end{array}$ & $1(3 \%)$ & $9(3 \%)$ & $16(53 \%)$ & $4(13 \%)$ & - & $30(100 \%)$ \\
\hline 3 & $\begin{array}{l}\text { Will force me to do difficult } \\
\text { task }\end{array}$ & $1(3 \%)$ & - & $29(97 \%)$ & - & - & $30(100 \%)$ \\
\hline 4 & $\begin{array}{l}\text { Will make me feel embarrassed while } \\
\text { presenting a demo lesson to my } \\
\text { colleagues }\end{array}$ & $1(3 \%)$ & $20(67 \%)$ & $6(20 \%)$ & $3(10 \%)$ & - & $30(100 \%)$ \\
\hline 5 & $\begin{array}{l}\text { Will force me to prepare number of } \\
\text { teaching materials }\end{array}$ & $1(3 \%)$ & $8(27 \%)$ & $18(60 \%)$ & $3(10 \%)$ & - & $30(100 \%)$ \\
\hline
\end{tabular}




\begin{tabular}{|l|l|l|l|l|l|l|l|}
\hline 6 & $\begin{array}{l}\text { Going to enjoy fully and will give me } \\
\text { an opportunity to appreciate myself for } \\
\text { choosing teaching as a career }\end{array}$ & - & $2(7 \%)$ & $7(23 \%)$ & $20(67 \%)$ & $1(3 \%)$ & $30(100 \%)$ \\
\hline
\end{tabular}

Tables 4,5 and 6 will reflect the teacher's perception, experiences and attitude towards the conduction of microteaching session after the conduction of the session.

Table4. Teacher's perception on the impact of microteaching on their teaching competence

\begin{tabular}{|l|l|l|l|l|l|l|l|}
\hline S.N. & Statements & SA & A & UD & D & SD & Total \\
\hline 1 & $\begin{array}{l}\text { Microteaching: helped me to develop } \\
\text { awareness of my teaching skills }\end{array}$ & $19(63 \%)$ & $9(30 \%)$ & $1(3 \%)$ & - & $1(3 \%)$ & $30(100 \%)$ \\
\hline 2 & $\begin{array}{l}\text { Gave me ap opportunity to improve } \\
\text { my planning }\end{array}$ & $19(63 \%)$ & $9(30 \%)$ & $1(3 \%)$ & - & $1(3 \%)$ & $30(100 \%)$ \\
\hline 3 & $\begin{array}{l}\text { Helped me to develop the actual } \\
\text { teaching skills needed for } \\
\text { professional teaching }\end{array}$ & $20(67 \%)$ & $8(27 \%)$ & $1(3 \%)$ & - & $1(3 \%)$ & $30(100 \%)$ \\
\hline 4 & $\begin{array}{l}\text { Gave me an opportunity to apply my } \\
\text { learnt skills }\end{array}$ & $20(67 \%)$ & $8(27 \%)$ & $1(3 \%)$ & - & $1(3 \%)$ & $30(100 \%)$ \\
\hline 5 & $\begin{array}{l}\text { Helped me in determining my } \\
\text { strength and weakness }\end{array}$ & $18(60 \%)$ & $10(33 \%)$ & $1(3 \%)$ & - & $1(3 \%)$ & $30(100 \%)$ \\
\hline 6 & $\begin{array}{l}\text { Gave me an opportunity to learn by } \\
\text { observing others }\end{array}$ & $18(60 \%)$ & $10(33 \%)$ & $1(3 \%)$ & - & $1(3 \%)$ & $30(100 \%)$ \\
\hline 7 & $\begin{array}{l}\text { Made me aware of what makes a } \\
\text { good teacher }\end{array}$ & $20(67 \%)$ & $8(27 \%)$ & $1(3 \%)$ & - & $1(3 \%)$ & $30(100 \%)$ \\
\hline 8 & $\begin{array}{l}\text { Encouraged me to learn classroom } \\
\text { management }\end{array}$ & $19(63 \%)$ & $9(30 \%)$ & $1(3 \%)$ & - & $1(3 \%)$ & $30(100 \%)$ \\
\hline 9 & $\begin{array}{l}\text { Encouraged me to develop } \\
\text { autonomy }\end{array}$ & $20(67 \%)$ & $8(27 \%)$ & $1(3 \%)$ & - & $1(3 \%)$ & $30(100 \%)$ \\
\hline 10 & $\begin{array}{l}\text { Helped me to learn how to organize } \\
\text { and manage the time frame. }\end{array}$ & $19(63 \%)$ & $9(30 \%)$ & $1(3 \%)$ & - & $1(3 \%)$ & $30(100 \%)$ \\
\hline
\end{tabular}

Table5. Teacher's prediction on the effectiveness of the session

\begin{tabular}{|l|l|l|l|l|l|l|l|}
\hline S.N. & Statements & SA & A & UD & D & SD & Total \\
\hline 1 & $\begin{array}{l}\text { Microteaching: helped me to boost } \\
\text { my confidence in speaking fluently }\end{array}$ & $28(93 \%)$ & - & $1(3 \%)$ & - & $1(3 \%)$ & $30(100 \%)$ \\
\hline 2 & $\begin{array}{l}\text { Encouraged me to apply that ideas } \\
\text { that I have learned in different } \\
\text { course }\end{array}$ & $28(93 \%)$ & $1(3 \%)$ & $1(3 \%)$ & - & $1(3 \%)$ & $30(100 \%)$ \\
\hline
\end{tabular}


International Journal of Engineering Applied Sciences and Technology, 2020

Vol. 5, Issue 8, ISSN No. 2455-2143, Pages 198-206

Published Online December 2020 in IJEAST (http://www.ijeast.com)

\begin{tabular}{|l|l|l|l|l|l|l|l|}
\hline 3 & $\begin{array}{l}\text { Helped me to determine the } \\
\text { Learning objectives }\end{array}$ & $26(87 \%)$ & $2(7 \%)$ & $1(3 \%)$ & - & $1(3 \%)$ & $30(100 \%)$ \\
\hline 4 & $\begin{array}{l}\text { Helped me to write an effective } \\
\text { lesson plan }\end{array}$ & $25(83 \%)$ & $3(10 \%)$ & $1(3 \%)$ & - & $1(3 \%)$ & $30(100 \%)$ \\
\hline 5 & $\begin{array}{l}\text { Helped me to use my teaching aids } \\
\text { effectively }\end{array}$ & $28(93 \%)$ & - & $1(3 \%)$ & - & $1(3 \%)$ & $30(100 \%)$ \\
\hline 6 & $\begin{array}{l}\text { Gave me the confidence to stand } \\
\text { and talk before a class }\end{array}$ & $26(87 \%)$ & 2 & $1(3 \%)$ & - & $1(3 \%)$ & $30(100 \%)$ \\
\hline
\end{tabular}

Table6. The attitude of the teacher's towards micro teaching

\begin{tabular}{|c|c|c|c|c|c|c|c|}
\hline S.N. & Statements & SA & $\mathbf{A}$ & UD & D & SD & Total \\
\hline 1 & Consumed lot of my time & $1(3 \%)$ & - & $1(3 \%)$ & $28(93 \%)$ & - & $30(100 \%)$ \\
\hline 2 & Made me feel bored and stressed & $1(3 \%)$ & - & $1(3 \%)$ & $28(93 \%)$ & - & $30(100 \%)$ \\
\hline 3 & $\begin{array}{l}\text { Forced me to do difficult } \\
\text { task }\end{array}$ & $1(3 \%)$ & $8(27 \%)$ & $1(3 \%)$ & $20(67 \%)$ & - & $30(100 \%)$ \\
\hline 4 & $\begin{array}{l}\text { Made me feel embarrassed while } \\
\text { presenting a demo lesson to my } \\
\text { colleagues }\end{array}$ & $1(3 \%)$ & $2(7 \%)$ & $1(3 \%)$ & $26(87 \%)$ & - & $30(100 \%)$ \\
\hline 5 & $\begin{array}{l}\text { Forced me to prepare number of } \\
\text { teaching materials }\end{array}$ & - & $22(73 \%)$ & $1(3 \%)$ & - & 7 & $30(100 \%)$ \\
\hline 6 & $\begin{array}{l}\text { Enjoyable and gave me an } \\
\text { opportunity to appreciate myself for } \\
\text { choosing teaching as career }\end{array}$ & $28(93 \%)$ & - & $1(3 \%)$ & - & 1 & $30(100 \%)$ \\
\hline
\end{tabular}

microteaching, Certificate of appreciation has been presented to all the presenters. The format of the certificate is attached in Annexure-III.

\section{CONCLUSION}

Microteaching serves as a necessary training tool for pre-service as well as in-service teachers to improve their core competencies related to the teaching learning process. It also helps to increase the level of confidence of the teachers while teaching and demonstrating the content in an atmosphere of friendliness and equanimity. It can be concluded that learning is a lifelong process especially for the teachers. Learning is nothing but the positive change in behaviour by experience or training at any age. In accordance with these findings, it can also be concluded that micro teaching practices should be included as a part of the routine process of any education organization where it can contribute to improve the attitude and perception of the teachers towards teaching profession. At the end of the session of

\section{ACKNOWLEDGEMENT}

The author thanks to Mr. Dhruv Tiwari, Director and Mr. Hemat Goyal, Chairman, Delhi Public Elementary School, Indore for their inspiring support. The author would also like to thank the entire Delhi Public Elementary School fraternity for their direct and indirect support.

\section{Funding Sources: Nil}

\section{Conflict of Interest: None}

\section{Author's Profile}

Yogesh Popat has received his Bachelor of Engineering (Hons.) in Electronics \& 


\section{International Journal of Engineering Applied Sciences and Technology, 2020 \\ Vol. 5, Issue 8, ISSN No. 2455-2143, Pages 198-206 \\ Published Online December 2020 in IJEAST (http://www.ijeast.com)}

Telecommunication in 2011 and Master of Technolgy (Hons.) in Electrical Engineering in 2014. He Worked as Asst. Prof. at Rungta college of Engineering and Technology, Raipur, Chhattisgarh, India, As a PGT Physics at N. H. Goel World School Raipur, Chhattisgarh, As a PGT Physics and Coordinator at Taurian World School Ranchi, Jharkhand, India. Currently He is working as a Principal and Teacher-Physics at Delhi Public Elementary School, Indore, M.P, India. His Field of Interests is Power Electronics, Electricity and Education.

\section{REFERENCES}

[1] Yasmin Godek Atluk, Volkan Hasan Kaya, Dilber Bahceci, A study on developing Microteaching Scale for the student teachers, Elsevier Procedia - Social and behavioral Sciences 46, 2012, PP 2964-2969, doi:10.1016lj.sbspro.2012.05.598.

[2] Dr. Raviknat.2017, Microteaching: Attitude and perception of students and teachers Educators, International Journal of Current Research, Volume 9, Issue 9, September 2017, PP 58385-58388.

[3] Ugur Abakay, Fikret Alinack, Hayri Demir, The effects of microteaching practices on preservice physical education and sport teacher's attitudes towards teaching profession, European journal of Education Studies, Volume 2, Issue 9, 2016, ISSN 2501-1111, PP 127-135.

[4] Stanka Hadzhikoleva, Emil Hadzhhikolev, Nikolay Kasakliev, Using Peer Assessment to Enhance Higher Order Thinking Skills, TEM Journal, Volume 8, Issue 1, ISSN 2217-8309, Feb. 2019, PP 242-247, doi: 10.08421/TEM81-34.

[5] Barak, M. \& Dori, Y.J, enhancing higher order thinking skills amomg inservice science teacher training via embedded assessment, Journal of Science Teacher Education, 20(5), 2009, PP 459474.

[6] King, F., Goodson, L. Rohani, F., (1997), Higher Order thinking skills- Definition, Teaching Strategies, Assessment, Publication Centre for Advancement of Learning and Assessment.

[7] Shilpashree Yeliyur Dhananajaya, Aliya Nusrath, Effectivness of Micro teaching workshop designed to improve the teaching performance of post graduate medical students, International journal of research in medical sciences June 2018, PP 1982-1985, dx.doi.org: 10.18230/23206012.ijrms.20182273.
[8] Goregn, The Effect of Microteaching Practices on Student Teachers' Views of Giving Lessons In the Classroom, Journal of Hacettepe University Education Faculty, 24, 56-63.

[9] Amobi, F. A. (2005). Pre-service teachers ${ }^{\text {ee }}$ reflectivity on thesequence and consequences of teaching actions in a microteachingexperience. Teacher Education Quarterly, 32(1),115-128.

[10] Le Maistre, C., \& Pare, A. (2010), whatever it takes: How beginning teachers learn to survive. Teaching and Teacher Education, 26,3, 559-564.

[11] Imran Mahmud, Shariahar Rawshon, Micro Teaching to Improve Teaching Method: An Analysis on Students' Perspectives, IOSR-JRME, Volume 1, Issue 4, May-June 2013, ISSN 23207388, PP 69-76.

[12] Passi BK, Shah MM, Microteaching in teacher Education, In: CASE Monograph, Volume 3, Baroda Centre of Advanced Study in Education, MS University of Baroda; 1976.

[13] Higgins A, Nicholl H., The experiences of lectures and students in the use of microteaching as a teaching strategy. Nurse Edu Pract 1996: 238-47.

[14] Ramesh A., Microteaching an efficient technique for learning effective teaching. J Res Med Sci 2013;18: 158-63.

[15] Elias S.K, Pre-Service Teachers' Approaches to the effectiveness of Micro-Teaching in Teaching Practice Programs, Open Journal of Social Science, 2018,6, PP 205-224, https://doi.org/10.4236/jss.2018.65016.

[16] Koross,R., Micro-teaching an efficient Techinque for Learning Effective Teaching Skills: Pre-Service Teachers' Perspective, IRA International Journal of Education and Multidisciplinary studies, ISSN 2455-2526, 4(2), PP 289-299.

https://dx.doi.org/10.21013/irajems.V4.n2P7.

[17] ChawlaV, Thukral P, Effects of student feedback on teaching competence of student teachers, a microteaching experiment Contemp Educ Technol 2011;2; PP 77-87.

[18] Pandchuk K, Hardley D, Cook D, Effectiveness of brief workshop designed to improve teaching performance at the University of Alberta, Academic Medicine, 2004;79; PP 798804.

[19] Lazarus, E. and Olivero, F. 2009. 'Video Papers as a tool for reflection on practice as initial 
teacher education. Technology, Pedagogy and Education, 18(3), 258-268.

[20] Atma Ram Sahu (1984) Microteaching: some research studies and research questions, International Journal of Mathematical Education in Science and Technology, 15:6, 727-735, DOI: $\underline{10.1080 / 0020739840150608}$ 